\title{
Namigi Miroslava Grepla, kako naprej v skladnji
}

\author{
Andreja Žele
}

Cobiss: 1.19

Miroslav Grepl, Jak dál v syntaxi, ur. Jan Dvořák - Petr Malčík, Brno: Vydavatelství Host, 2011 (Studie osobností brněnské lingvistiky 4), 248 str.

Zbrane razprave Miroslava Grepla Jak dál v syntaxi so četrta knjiga iz zbirke študij osebnosti brnskega jezikoslovja, ki jo urejata Jan Dvořák in Petr Malčík. Treba je omeniti še dve znani jezikoslovni imeni, in sicer v recenzentskih vlogah: Petra Karlíka (z Masarykove univerze v Brnu) in Macieja Henryka Grochowskega (z Univerze Nikolaja Kopernika v Torunju).

Raznovrstno jezikoslovno delovanje Miroslava Grepla je predstavljeno v petih tematskih poglavjih: Preroditeljska češčina (Obrozenská čeština, 13-48), Teorija verza (Teorie verše, 51-58), Ilokucijska dejanja - njihova tipologija, realizacija in indikacija (Ilokuční akty - jejich typologie, realizace a indikace, 61-144), Čustva in govor (Emoce a řeč, 147-154) ter Slovnica in pomenoslovje (Gramatika a sémantika, 157-221); sledi še bibliografija Miroslava Grepla za leta 1955-2004, ki jo je sestavil Petr Malčík (223-238).

Monografija je v bistvu zbir Greplovih razprav o besediloslovju v češčini in na Češkem in po naslovu lahko sklepamo, da je besedilna skladnja tudi osnovna perspektiva nadaljnjih skladenjskih obravnav.

Večina nas, slovenistov in slavistov, ime Miroslava Grepla povezuje z razpravami o zlasti češki skladnji. Konkretno nas spremljata vsaj dve temeljni deli, in sicer tretji del češke akademijske slovnice Mluvnice češtiny 3: skladba (Praha: Academia, 1987), kjer je Grepl eden od soavtorjev, in visokošolski učbenik, kot ga je označil sam Grepl, Skladba češtiny (Praha: Votobia, 1998), ki je nastal v soavtorstvu s Petrom Karlíkom.

Greplovo stališče je, da je kompleksna obravnava skladnje uresničljiva samo v smislu obravnave soodvisnosti v celotnem jezikovnem sistemu, ker aktualizira tako oblikovno-izrazni in pomenski kot pragmatični in besedilotvorni pomen. Skladnjo spremlja razvojno, pomensko, prek slovničnih zgradb in obravnave naklonskosti v najširšem smislu do skladenjske prozodije znotraj komunikacije. Tu bodo povzeti in komentirani samo tisti poudarki oz. ugotovitve (z navedeno stranjo v oklepajih), ki nakazujejo osnovni namen zbranih obravnav Kako naprej v skladnji. 
- Že v tridesetih in štiridesetih letih 19. stoletja, tj. v obdobju konstituiranja moderne knjižne češčine, lahko govorimo o razvoju skladnje govora na vseh funkcijskih področjih jezika (13) - vpliv govora na spremembe oz. razvoj skladnje je zlasti opazen $v$ besednem redu. Ukinjajo se nenaravnejše/umetelnejše zgradbe, prodira naravnejši besedni red iz govora, neskladje med funkcijsko rabo jezika v praksi in teoriji je očitno in se omejuje na jezikovno pravilnost (20). Stilistika že sega v bistvo govorjene češčine in tako postaja vzorec dobre žive jezikovne rabe postopno že protiutež suhim ali celo togim slovničnim pravilom. Obravnava sorazmerno kratkega obdobja, npr. prve polovice 19. stoletja, lahko dá pregled notranjih in zunanjih dejavnikov v jeziku in njihovo součinkovanje.

- Soodvisnost in součinkovanje naravnega govora nasproti verzu omogoča tudi opredelitev verza kot členitve glede na poudarjen ritem, ki ga narekuje naglas, pri svobodnem verzu pa zlasti intonacija (56).

- Greplovo razumevanje besedne komunikacije je strnjeno v dvanajst kratkih poglavij s skupnim naslovom Kaj delamo, ko govorimo (61-111). Tu je tudi eksplicitno poudarjen pragmatični vidik - tj., ni pomembno samo razumeti vsebino sporočila, ampak tudi, zakaj se nekaj sporoča; slednje, tj. vzrok in posledica, sta v določenih tipih besedil (npr. publicističnih) celo pomembnejša. Tu se avtor sklicuje zlasti na temeljna dela Johna L. Austina in Johna R. Searla. Z vidika jezikoslovne pragmatike Miroslava Grepla zanimajo zlasti jezikovni indikatorji oz. prvine, ki vplivajo na uspešnost uresničitve in sprejemanja komunikacijskih namenov govorečega oz. kako naslovnik prepozna namero; torej je poleg vsebine denotata bistvena tudi vsebina odnosa oz. razmerja, slednja pa pogosto prevlada, tako da je poleg tega, kaj je nekdo izrekel, pomembno tudi, kaj je s tem naredil, npr. oseba A: Skočim na postajo po vozovnico, oseba B: Tu imam avto; oseba A: Z Južne Morave so mi prepeljali vino, oseba B: Tu imam avto (62). Torej ko nekaj izrečem, $\mathrm{s}$ tem tudi nekaj naredim, s čimer je mišljen zlasti učinek, ki ga določena vsebina povzroči v razmerju. In če komunikacijsko dejanje ni uspešno, sledi odziv: Kaj s tem mislišs? in Kako to misliš?

- Miroslav Grepl opredeljuje poved kot elementarno besedilno enoto oz. kot elementarno besedilo, v katerem se lahko zazna aktualna komunikacijska (ilokucijska) vloga in moč. Vsebina povedi se razlikuje od njene komunikacijske vloge, ki zgolj oznanja ali poziva, sprašuje, ukazuje itd. Ko pa isto vsebino izgovarjamo v različnih situacijah delovanja oz. komunikacijskih situacijah, lahko obvelja rečenica »Govori eno, dela drugo!« (67). So pa povedi oz. izreki, v katerih je vsebina prekrivna s komunikacijsko vlogo, npr. Živjo!, Samo prek mojega trupla! ipd. Do prave besedilne koherence v smislu medpropozicijske udeleženske soodvisnosti in glagolske sopojavnosti pa pride $\mathrm{v}$ smiselno in funkcijsko zaključeni nadpovedni ali nekajpovedni komunikacijski enoti ( $\mathrm{v}$ češčini je ta enota poimenovana »promluva«).

-Znotraj komunikacijskega položaja je bistveno, ali je komunikacijsko dejanje naravnost posredovano ciljnemu naslovniku, ki ga v smislu interakcijske stimulacije obvezuje nujnost odziva oz. odgovora, ali pa je navadno enosmerno namenjeno priložnostnemu naslovniku. Ilokucijska vloga oz. moč posredovane vsebine je vezana na komunikacijsko situacijo oz. kontekst, ki obsega mesto komunikacijskega dejanja, družbeno-čustvena razmerja med komunikanti, mero izkušenosti udeležencev v 
komunikaciji, predvédenje o že izrečenem in učinke na že izrečeno (78). Izrečena vsebina v komunikacijskem kontekstu dobi svoj smisel, npr. Ta led je še tanek, Danes imajo pri Čadu fižol, Je že zvonilo ipd. (79). Najbolj neposredno in eksplicitno se ilokucijska dejanja vplivanja lahko uresničijo s performativi, npr. Oznanjam vam ..., Obveščam vas ..., Sprašujem te, ali ..., S tem se obvezujete, da ... (85).

- Med leksikalnimi sredstvi so v ospredju členki, med kategorijami vid, čas in naklon, skladenjsko je poleg besednega reda (npr. zaznamovanega Samo opazoval je s prekrižanimi rokami) pomemben stavčni poudarek (npr. Vsaj telefoniral bi $m u ? !)$ in intonacija sploh (92). Bistvena ilokucijska vloga členka se odraža v primerih kot Groza se ti je tam jeziti, Kot pribito pridem, Bognedaj da bi začelo deževati, Ve se, da ga spet ne bo!, Dejstvo je, da o tem ne vem nič, Ljubeznivo me opravičite, $\underline{T o}$, to sem želela od tebe ipd. (100). Členki so (po)govorna aktualizacija že obstoječega govornega dejanja oz. sporočila, in sicer so s komunikacijskega vidika lahko usmerjeni navzven (t. i. eksocentrični členki) in obarvani subjektivno, npr. Očitno ga ne briga, $\underline{O}$, da bi se že enkrat spametoval ..., ali s samozadostno poudarjalno vlogo (t. i. endocentrični členki), npr. Samo to je čakal, torej zdaj gre lahko naprej. (140-143) Navezava naklonskosti na polnopomenski glagol se izrazno potrjuje, ko se morati in dokončati oblikujeta v npr. To delo se je moralo končati.

- Lahko govorimo o ustaljenih povednih zgradbah npr. za svarilo, npr. Da si ne drzneš odpreti!, Da ti ne pride na misel!, za zavrnitev, npr. Zakaj bi ga klical?!, Kaj imaš ti tam za delati?!, ali očitek, npr. A si morala to narediti?! Z vidika skladenjskega naklona naj bi bile prvotnejše pritrdilne, vprašalne, velelne in želelne povedne oblike, druge oblike povedi pa naj bi bile le različice oz. modifikacije prvotnejših. Vprašanje je, ali gre zares za skladenjsko že ustaljene oblike povedi ali le za določeno stopnjo ustaljenosti določene oblike povedi glede na ustrezno ilokucijsko dejanje, npr. A bi si naročili eno kavo? - Veš kaj, naročimo si eno kavo! - No, a si naročimo eno kavo?! - Dajmo si naročiti eno kavo! (95)

- Pod dinamično razumljeno soodvisno-posledično navezo jezik - govor besedilo se razume interdisciplinarna soodvisnost $\mathrm{v}$ raziskavi jezika, poleg skladenjskega in pomenskega pa je treba poudariti tudi pragmatični vidik in procesualno (nestatično, ustvarjalno) sledenje pomenu in vlogi posamezne jezikovne enote (96). S pragmatičnega vidika so glagolske oblike prve osebe množine tudi posebne, npr. Zaigrajmo šah v smislu 'Pojdimo igrat šah' nasproti Varujmo naše gozdove kot poziv k družbeno pomembni dejavnosti, ki traja (97). V igri so kategorije vid, čas, naklon, npr. Za koliko preskočiš to oviro?, Zakaj bi se mu opravičeval?!, ki samo poudarjajo komunikacijsko-pragmatično vlogo. Treba je poudariti odvisnost vida in časa od konteksta (159).

- Z vidika komunikacijske situacije so za učinkovito komunikacijo pomembne predpostavke govorečega o naslovniku (kaj že ve, kaj je sposoben opraviti, katera so njegova nagnjenja, želje, zanimanja in kakšna so njegova vrednotenjska merila), stališča govorečega do sporočanega (spoznavnostna stopnja veljavnosti sporočane vsebine, prednostne prvine, vrednotenjske prvine, čustvenostne prvine) in lastna ilokucijska namera govorečega (ki je lahko neposredna, npr. Posodi mi deset evrov, ali posredno naklonsko oblikovana, npr. Ali mi lahko/mogoče (lahko)/ morda (lahko) posodiš deset evrov?). 
- V živi aktualni vsakdanji komunikaciji ima torej ista vsebina lahko različen smisel in različno ilokucijsko moč, npr. Dedek je bolan? - Dedek je menda bolan?! - Dedek kot da je bolan. - Zdi se, da je dedek bolan ... Pomembne so tudi kategorialne spremembe, npr. nikalnost, vid: Moral bi ga poklicati/*klicati-Ne bi ga smel poklicati/klicati, ki pa se znotraj iste sporočilnosti lahko tudi nevtralizirajo v smislu Si lačen?/Nisi lačen?, Ne sporoča, da je bolan, Ne sporoča, da bi bil bolan ipd.

- Ilokucijska dejanja so v bistvu vrednotenjska dejanja in v nadaljevanju bi bila potrebna njihova razvrstitev oz. kar taksonomija ilokucijskih dejanj. Z vidika uspešnosti ilokucijskega oz. vplivanjskega učinka lahko utemeljujemo, zakaj kdaj izberemo jezikovno neposredno ubeseditev ali pa posredno naklonsko ubeseditev in zakaj tehtamo med normo in komunikacijskim učinkom. Pomembno je poudariti vrednost hkratnega/istočasnega izrekanja in delovanja, kar je v jezikih lahko univerzalni pojav tako kot različne naklonske prvine, nikalnost, besedni red, poudarki, intonacija, členki ipd. Primeri združene uporabe členkov in intonacije so npr. Vendar sem ga spoznal 'Kljub vsemu sem ga spoznal' nasproti Vendar sem ga spoznal 'Končno mi ga je uspelo spoznati'.

- Pretvorba med drugim lahko opozarja tudi na izvorno notranjo naklonskost, npr. Ležali smo tudi v veži > Ležalo se je tudi v veži nasproti npr. Stoli so ležali tudi $v$ veži $>$ *Ležalo se je tudi v veži/Vse mogoče je ležalo tudi v veži (z naklonskostjo zunanjega opazovalca).

- Kot strukturalist se Grepl ekspresivnosti loteva v vseh segmentih jezikovnega sistema, na leksemski ravni se dotakne leksemov kot zadah in smrad, gobec in usta, brdavs in silak, dolgčas in morija, na skladenjski razlaga sporočilne zmožnosti primerov kot Vi to tako razumete!, Potem pa tja skoči!, Si lačen?/Nisi lačen?, Ostani tukaj! nasproti Ostaneš tukaj?, kjer je pomembna intonacija, poleg nje tudi besedni red v soodvisnosti s stavčnopovednim poudarkom, npr. Celo življenje je čakal na to; stavčnopovedni poudarek ločuje antikadenco v potrditvenem vprašanju Kaj ko bi mu napisal? nasproti postopni kadenci v ponudbi Kaj ko bi mu napisal.

Miroslav Grepl načelno zagovarja doslednejši pomenski pristop k obravnavi skladnje, ker po njegovem mnenju dobro združuje še vse druge vidike, tako funkcijskega kot zgradbenega in izraznega. Meni tudi, da je za boljšo problemsko obravnavo tudi skladnje potrebnih zlasti več kontrastivnih študij.

Sicer pa naslov zavaja, ker obljublja metodološke smernice v nadaljnjih obravnavah skladnje, ki pa jih ne dobimo. Z zbranimi oz. izbranimi prispevki Miroslava Grepla pa se pomenljivo nakazuje, da so njegove skladenjske obravnave vsaj zadnja tri desetletja usmerjene tudi v besedilo in širši kontekst. In pri tem v češkem prostoru ni bil osamljen; naj omenim samo še Josefa Hrbáčka in njegovo monografijo o osnovnih pojmih in opredelitvah besedilne skladnje Nárys tekstové syntaxe v spisovné češtiny (Praha: Trizonia, 1994).

Razumljivo je, da je besedilo z jezikovno in nejezikovno okolico danes središče zanimanja in zato osrednja skladenjska enota, iz katere izhaja vse pomensko-skladenjsko, morfološko in morfonološko preučevanje. In s tem se še potrjuje tudi Greplov izhodiščni strukturalni pristop, ki zagovarja hierarhično soodvisnost jezikovnih prvin in pojavov tako znotraj ravnin kot med ravninami jezika. 